\title{
Exploring the global animal biodiversity in the search for new drugs - marine invertebrates
}

\author{
Dennis RA Mans* \\ Department of Pharmacology, Anton de Kom University, Paramaribo, Suriname
}

\begin{abstract}
Man has probably used since his existence plants and plant-derived compounds for his health care and well-being. This has led to the development of life-saving drugs for treating a multitude of conditions including infectious, cardiovascular, malignant, and diabetic disease. More recently, the amazing biodiversity represented by the world's oceans have been realized to represent an equally and exceptionally rich source of valuable bioactive compounds. The majority of marine organisms have an evolutionary history that dates back to the Cambrian, some 500 million years ago. Since then, these organisms have dealt successfully with competitors and predators by developing a unique arsenal of highly effective secondary metabolites for their defense, reproduction, and communication. Many of these chemicals affect metabolic pathways that are common to humans and are involved in critical physiological functions. Thus, these substances often possess meaningful pharmacological properties. For these reasons, marine organisms may represent precious resources for developing drug candidates, cosmetics, nutritional supplements, and molecular probes for improving our well-being. This paper addresses the significance of bioactive compounds from marine invertebrates to the development of new drugs.
\end{abstract}

\section{Introduction}

Historically, terrestrial plants and microorganisms have been important natural sources for developing new medicines [1,2]. In fact, approximately $75 \%$ of the twenty most commonly used hospital drugs, and approximately $20 \%$ of the hundred most prescribed drugs are derived from natural sources [3]. A few examples are antibiotics such as penicillin and streptomycin derived from the fungus Penicillium chrysogenum (Trichocomaceae), and aminoglycosides such as gentamicin and tobramycin from Streptomyces and Micromonospora bacteria, respectively; the narcotic morphine and the antitussive codeine derived from the opium poppy Papaver somniferum L. (Papaveraceae); the cardiotonic digoxin from the foxglove Digitalis purpurea L. (Plantaginaceae); the antimalarial quinine derived from the bark of Cinchona spp (Rubiaceae); and the skeletal muscle relaxant tubocurarine from the stem of Chondrodendron tomentosum Ruiz \& Pavón (Menispermaceae) that is used for general anesthesia [1,2].

These and many other examples underscore the importance of plant-derived compounds - particularly those from tropical rain forests - to new drug discovery and development activities [1,2]. However, the world's oceans may represent an equally important resource for discovering and developing new therapeutics. This statement is based on two important pieces of evidence. Firstly, the oceans cover more than $70 \%$ of the earth's surface and contain more than 200,000 species of invertebrates and algae as well as an unknown number of microorganisms, only a relative handful of which has been studied [4]. Secondly, the relatively small number of marine organisms evaluated to date - mostly algae and invertebrates - has already yielded thousands of chemical compounds that have found medical applications ranging from algae-based skin care products $[5,6]$ to established antineoplastic agents such as cytarabine [7].

This paper provides the rationale for marine drug discovery and development, addresses a number of bioactive compounds from marine invertebrates, elaborates about their mechanisms of action, focuses on their potential clinical usefulness and applicability, and reflects on the prospects for new discovery and development activities based on the exploration of these compounds. The compounds have been grouped on the basis of the taxonomic groups ([sub]phyla) in which they have been encountered (Table 1).

\section{Background}

Why do marine species including invertebrates produce such an abundance of compounds with unusual chemical structures and unique mechanisms of action upon which molecular modeling and chemical synthesis of new drugs can be based? An important part of the answer to this question lies in the fact that many of them are sessile organisms that live in densely populated habitats where competition for space and resources is intense. Examples are reef-building corals, sponges, sea fans, bryozoans, and tunicates. Indeed, a superficial examination of a coral reef habitat reveals an astonishing density of such plants and animals. All of them compete with each other for food and space, must avoid attack by predators and being fouled or overgrown, need to reproduce successfully, and must ward off microbial infections. For these purposes, they have developed an exceptional arsenal of secondary metabolites for their defense, reproduction, and communication $[8,9]$.

Some of these chemicals are toxic or noxious, conferring protection against predators; others suppress the growth and reproduction of rivals, thus preventing their overgrowth and crowding out and allowing

Correspondence to: Prof. Dr. Dennis R.A. Mans, Department of Pharmacology, Faculty of Medical Sciences, Anton de Kom University of Suriname. Kernkampweg 5, Paramaribo, Suriname, Tel/Fax: 597 441071; E-mail: dennis_mans@yahoo.com; dennis.mans@uvs.edu

Key words: marine invertebrates, novel structures, unique mechanisms, bioactive compounds, new drug discovery and development

Received: March 20, 2016; Accepted: April 22, 2016; Published: April 25, 2016 
Table 1. Bioactive compounds with potential clinical applicability derived from a number of marine species of invertebrates grouped according to the phyla in which they have been encountered.

\begin{tabular}{|c|c|c|c|}
\hline Phylum & Species (Family) & Compound & (Potential) clinical application(s) \\
\hline \multirow[t]{6}{*}{ Porifera } & TopsentiapachastrelloidesTopsent, 1892 (Halichondriidae) & Bisindole alkaloids & Against bacterial infections including those caused by MRSA \\
\hline & Petrosiacontignata Thiele, 1899 (Petrosiidae) & Contignasterol & Against asthma and hemodynamic disorders \\
\hline & $\begin{array}{l}\text { Stylotellaaurantium Kelly-Borges \&Bergquist, } 1988 \\
\text { (Halichondriidae) }\end{array}$ & Debromohymenialdisine & Against cancer, Alzheimer'sdisease, and osteoarthritis \\
\hline & Discodermiadissoluta Schmidt, 1880 (Theonellidae) & $(+)$-Discodermolide & Against cancer \\
\hline & Halichondria okadaiKadota, 1922 (Halichondriidae) & Halichondrins & Against cancer \\
\hline & PseudaxinyssacantharellaLévi, 1983 (Halichondriidae) & Girolline & Against malaria \\
\hline \multirow[t]{2}{*}{ Cnidaria } & Pseudopterogorgiaelisabethae Bayer 1961 (Gorgoniidae) & Pseudopterosins & $\begin{array}{l}\text { Against skin irritation, as analgesics, for wound-healing, and } \\
\text { against inflammation }\end{array}$ \\
\hline & Jellyfish-associated marine fungi & - & Against microbial infections \\
\hline Nemertea & Paranemertesperegrina Coe, 1901 (Emplectonematidae) & Anabaseine & Against Alzheimer's disease \\
\hline \multirow[t]{4}{*}{ Mollusca } & Dolabellaauricularia Lightfoot, 1786 (Aplysiidae) & Dolastatin 10 & Against cancer \\
\hline & Elysiarufescens Pease, 1871 (Plakobranchidae) & Kahalalide F & Against cancer and skin conditions \\
\hline & SpisulapolynymaStimpson, 1860 (Mactridae) & Spisulosine & Against cancer \\
\hline & Conusspp. Linnaeus, 1758 (Conidae) & Ziconotide & Against chronic pain \\
\hline Bryozoa & Bugulaneritina Linnaeus, 1758 (Bugulidae) & Bryostatin 1 & Against cancer and Alzheimer's disease \\
\hline \multirow[t]{3}{*}{ Tunicata } & Lissoclinum sp. (Didemnidae) & Mandelalides & Against cancer \\
\hline & EcteinascidiaturbinataHerdman, 1880 (Perophoridae) & Trabectedin & Against cancer \\
\hline & Aplidiumalbicans Milne-Edwards, 1841 (Polyclinidae) & Plitidepsin & Against cancer \\
\hline Hemichordata & CephalodiscusgilchristiRidewood, 1908(Cephalodiscidae) & Cephalostatin 1 & Against cancer \\
\hline
\end{tabular}

them to maintain space; and still others serve as natural defenses against microbial infections $[8,9]$. As many of these chemicals also interact with enzymes and metabolic pathways involved in human diseases, they often represent valuable lead compounds for the development of new drugs for treating human diseases [8,9]. If, for example, a certain sponge produces a chemical that prevents a coral from invading its space by interfering with the coral's proliferation and cell division, that compound may also be effective in inhibiting the uncontrolled growth of cancer in humans. In fact, several marine-derived chemical compounds have been developed as antineoplastic agents, while some are under preclinical or clinical evaluation as a treatment for cancer. And more comprehensive studies on the bioactivities of these substances may well open the door to the development of many other medical applications ranging from novel antivirals to drugs against Alzheimer's disease.

\section{Bioactive compounds from Porifera}

The phylum Porifera (sponges) is evolutionarily considered the oldest group of existing animals, and probably represents one of the most important sources of marine natural products for developing new drugs. Their sessile life-style and abundant diversity - roughly 2,800 different species - were probably the driving evolutionary forces to develop their unique defensive toxins which have potent pharmacological activities. Notably, exploration of sponges as sources of new drugs led in the 1950s to the identification of a number of unusual arabinose nucleosides in Tectitethya crypta (Tethyidae) in the waters off Bimini Islands, Bahamas [10], and the subsequent development of the antimetabolite cytarabine (cytosine arabinoside, ara- $\mathrm{C}$, or Cytosar ${ }^{\circ}$ ), an essential component of combination chemotherapeutic regimes for treating several hematological malignancies [7]. Further exploration of marine sponges for their medicinal potential led to the identification of some highly interesting bioactive compounds including bisindole alkaloids, contignasterol, debromohymenialdisine, (+)-discodermolide, halichondrins, and girolline.

\section{Bisindole alkaloids}

The bisindole alkaloids cis-3,4-dihydrohamacanthin B and bromodeoxytopsentin have been isolated from the South African sponge Topsentia pachastrelloides Topsent, 1892 (Halichondriidae). Interest in these sponge metabolites arose following their potent and diverse pharmacological activities - including antimicrobial activity - in various preclinical models [11]. Further exploration of cis-3,4dihydrohamacanthin $B$ and bromodeoxytopsentin revealed potent and selective interference with pyruvate kinase (PK), a key hub protein in the interactome of methicillin-resistant Staphylococcus aureus (MRSA) as well as inhibition of the growth of $S$. aureus and MRSA in vitro $[12,13]$. MRSA - also known as the 'superbug' - is an exceptionally drug-resistant pathogenic bacteria that is responsible for a considerable number of fatalities in many public healthcare facilities throughout the world where resistant bacteria are selected due to pressure generated by the overuse of antibiotics [14,15].

Since PKs are evolutionarily highly-conserved rate-limiting enzymes for the irreversible conversion of phosphoenolpyruvate into pyruvate during glycolysis, they have been recognized as unprecedented targets for mechanistically novel antibiotics [16]. Indeed, targeting MRSA PK may represent a novel strategy for developing much needed new antibiotics against this drug-resistant pathogen [12]. This prospect not only spurred further research on natural marine bisindole alkaloids $[17,18]$, but also stimulated efforts directed at the synthesis of analogues with original chemical structures [19,20]. So far, however, the potent MRSA PK inhibition recorded in vitro could not be translated to meaningful MRSA antibacterial activity in vivo [18]. Still, the identification of these lead compounds holds the promise for the development of efficacious antibiotics against MRSA and other multidrug-resistant bacteria.

\section{Contignasterol}

The polyhydroxysteroid contignasterol (IZP-94005) was first isolated from the sponge Petrosia contignata Thiele, 1899 (Petrosiidae) in Papua New Guinea in the early 1990s [21]. This compound prevented histamine release by rat peritoneal mast cells induced by IgE, presumably by inhibiting phospholipase $\mathrm{C}$ activity [22]. Furthermore, contignasterol significantly inhibited acute antigen-induced 
bronchoconstriction in vitro as well as in vivo [23], and prevented allergen-induced plasma protein exudation in the tracheobronchial tree of sensitized guinea pigs [24]. All these observations pointed towards an important role for contignasterol as an anti-allergic, more specifically, anti-asthmatic drug. In addition, contignasterol inhibited platelet aggregation suggesting anti-thrombolytic activity [25]. Based on these and other observations, contignasterol is now being evaluated as a candidate for treating respiratory and hemodynamic disorders [25].

\section{Debromohymenialdisine}

Debromohymenialdisine is an alkaloid originally isolated from the marine sponge Stylotella aurantium Kelly-Borges \& Bergquist, 1988 (Halichondriidae). This organism is encountered in the shallow waters around the Republic of Palau, an island country in the western Pacific Ocean. Debromohymenialdisine inhibited cancer cell growth by a novel mechanism of action, viz. selective blockage of two kinases involved in the $G_{2}$ checkpoint [26]. This led to massive apoptosis in some cancer types [27] which was much more pronounced in vivo than in vitro [26] but the induction of only moderate cytotoxicity as well as radioprotection to normal cells [26-29]. For all these reasons, debromohymenialdisine is undergoing evaluation as an anticancer agent [30]. As aberrant kinase activities have also been linked to Alzheimer's disease [31], debromohymenialdisine is being tested as a remedy against this condition [32]. In the meantime, this compound has been licensed for commercial development as a possible treatment for osteoarthritis as it slowed joint and cartilage deterioration in laboratory animals [33].

\section{(+)-Discodermolide}

(+)-Discodermolide is a natural polyketide that was isolated in 1990 from the Bahamian deep-sea sponge Discodermia dissoluta Schmidt, 1880 (Theonellidae) (Figure 1) [34]. Preclinical studies showed that $(+)$-discodermolide potently inhibited the proliferation of several cultured (multidrug-resistant) cancer cell lines [35] by stabilizing their microtubules, leading to arrest of cell division in the M phase of the cell cycle [36]. The drug showed promising activity against pancreatic cancer and various other (inherently) drug-resistant malignancies [37], as well as appreciable synergy with paclitaxel in lung cancer [38]. Other noteworthy properties of (+)-discodermolide

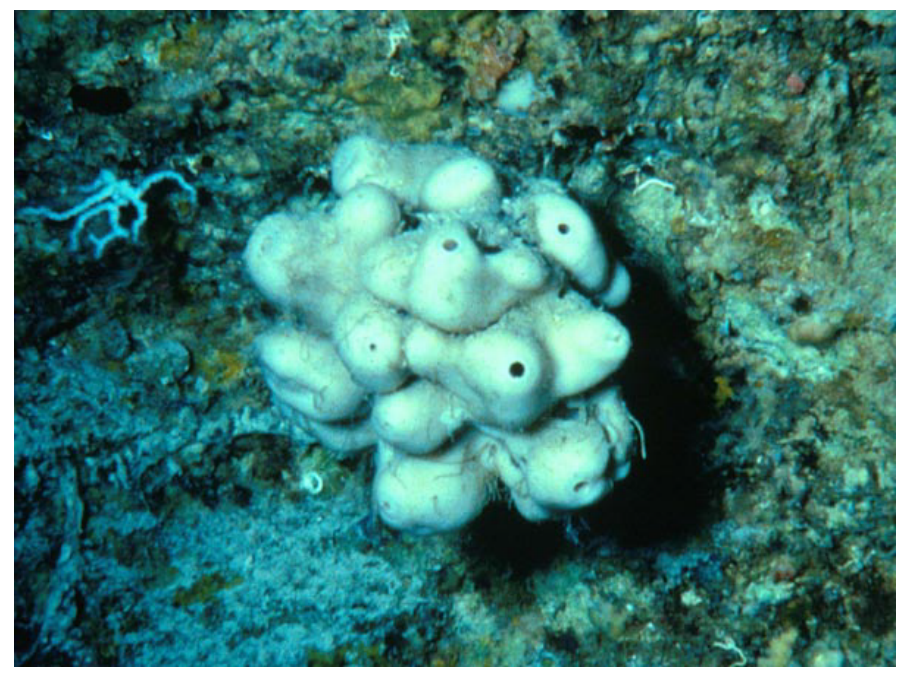

From: www.bu.edu

Figure 1. The deep-sea sponge Discodermia dissoluta (Theonellidae) are immunosuppressive activity [39] and potent acceleration of cell senescence [40]. For these reasons, clinical studies have been initiated to evaluate (+)-discodermolide for its efficacy against solid tumors, paclitaxel-resistant tumors, and/or in combination with paclitaxel.

\section{Halichondrins}

Halichondrins are polyether macrolides that were first isolated from the Japanese sponge Halichondria okadai Kadota, 1922 (Halichondriidae) [41]. Initial studies with halichondrin B revealed extraordinary in vitro and in vivo anticancer activity [42] by potent binding to tubulin at a site close to, but distinct from the vinca site, leading to alteration of tubulin depolymerization [43]. However, further studies were hindered by a lack of the natural product. For this reason, research efforts were redirected to the deep-water Pacific sponge Lissodendoryx sp. (Coelosphaeridae) that was available at sufficiently large quantities to yield halichondrins to continue their evaluation and development. This resulted in the isolation of isohomohalichondrin that showed encouraging preclinical anticancer activity [44]. This compound also prevented microtubule assembly [45] and caused delayed $S$ phase progression, mitotic block, and apoptosis in cancer cell lines [46]. Isohomohalichondrin B as well as a number of its synthetic analogues [47] are currently in clinical trials in patients with a wide range of malignancies.

\section{Girolline}

Girolline (or girodazole) is a 2-aminoimidazole derivative isolated from the New Caledonian sponge Pseudaxinyssa cantharella Lévi, 1983 (Halichondriidae) [48]. This compound was of interest as a potential anticancer agent, as it inhibited protein synthesis in eukaryotic cells at the termination steps rather than at the initiation or chain elongation steps like other known inhibitors such as emetine and homoharringtonine [49]. However, further development of girolline as an anticancer agent was discontinued when phase I clinical trials showed that it caused severe hypertension [50]. Fortunately, additional studies on girolline's bioactivity demonstrated inhibition of the growth of Plasmodium falciparum in vitro and in vivo as well as in vitro synergistic activity with chloroquine [51]. These observations suggest that girolline may represent a lead compound for new drugs to fight malaria.

\section{Bioactive compounds from Cnidaria}

The phylum Cnidaria contains over 10,000 species of aquatic, mostly marine animals and includes, among others, sessile sea anemones and corals as well as motile jellyfish and box jellies. These organisms are also called nettle-bearers because they attack their prey with their poisonous stinging cells called cnidoblasts. The venom of some species is extremely potent and their stings are very painful and can even be fatal to humans. The Cnidaria have yielded a few compounds with important biological activity such as the pseudopterosins. Furthermore, at least one species of Cnidaria harbors fungi that synthesize antimicrobials, presenting the opportunity of a novel way to produce these substances.

\section{Pseudopterosins}

The pseudopterosins are tricyclic diterpenepentose glycosides isolated from the sea whip Pseudopterogorgia elisabethae Bayer 1961 (Gorgoniidae), a Caribbean soft coral species (Figure 2) [52]. These compounds possess notable anti-inflammatory and analgesic properties that exceed the potencies of existing cyclooxygenaseinhibiting non-steroidal anti-inflammatory drugs [53-55]. They not only represent a new class of natural products [52], but also act through 


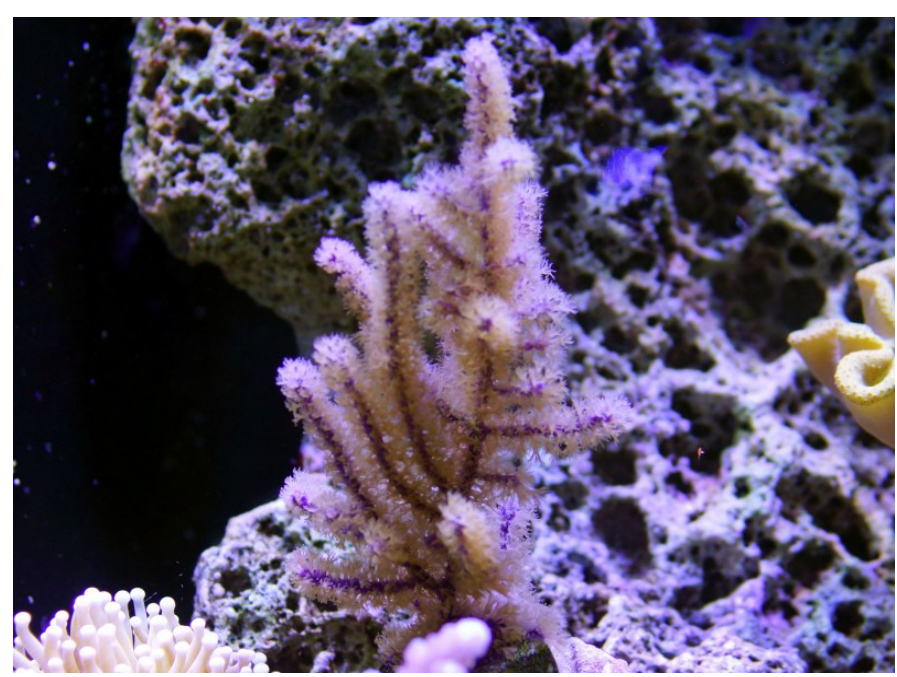

Figure 2. The sea whip Pseudopterogorgia elisabethae (Gorgoniidae) From: reefcorner.com

a novel mechanism that involves prevention of eicosanoid biosynthesis by inhibiting phospholipase A2, 5-lipoxygenase, and cyclooxygenase activity, and by preventing degranulation of leukocytes and the subsequent liberation of lysosomal enzymes [53,56,57]. For these reasons, extracts from $P$. elisabethae have been incorporated in a line of Estèe Lauder cosmetic products for treating skin irritation [58], while particularly pseudopterosins A to D are being evaluated for their use as analgesics as well as wound-healing and anti-inflammatory drugs [59-61].

\section{Jellyfish-associated marine fungi}

The jelly fish Nemopilema nomurai Kishinouye, 1922 (Rhizostomatidae) - also known as Nomura's jellyfish - is probably one of the largest cnidarians in the world, growing up to 2 meters in diameter and weighing up to 200 kilograms [62]. It is most often encountered in the waters of China, Korea, and Japan where it appears since 2003 in massive numbers, probably as a result of the favorable condition in these waters [63]. N. nomurai is toxic type of giant jellyfish [63]; its sting is painful and has been associated with adverse cardiovascular [64] as well as cytotoxic and hemolytic effects [65].

More recently, ethyl acetate extracts from cultivable fungi living in association with $N$. nomurai were found to exhibit meaningful activity towards the pathogenic bacteria Staphylococcus aureus (Staphylococcaceae) and Salmonella entrica (Enterobacteriaceae) and the plant pathogenic fungi Rhizoctonia solani (Ceratobasidiaceae) and Botrytis cinerea (Sclerotiniaceae) [66]. Importantly, the yield and type of the antimicrobials varied along with the cultivation conditions [66]. These observations suggest that N. nomurai - considered of low nutritional and economic value - may become a novel reservoir for the production of antibacterial and antifungal compounds.

\section{Bioactive compounds from Nemertea}

The Nemertea comprise a phylum of soft-bodied worm-like invertebrate animals also known as ribbon worms because of their unsegmented and smooth body. About 1,400 species are known, the majority of which are marine, but some are freshwater, and a few live on land [67]. Most nemerteans are carnivores feeding on annelids, clams, and crustaceans [67]. For this purpose, many possess a proboscis that turns inside-out to emerge just above the mouth, coils around the prey, paralyzes it by sticky, venomous secretions, and draws it into its mouth [68]. Others have a stylet, a calcareous barb, with which they stab the prey many times to inject toxins and digestive secretions after which it is swallowed whole [68].The venom is also used as a feeding deterrent against predation [69]. An important bioactive compound from nemertean venom is anabaseine.

\section{Anabaseine}

Anabaseine is a nicotinoid alkaloid that was isolated in the early 1970 s from various nemertine worms including Paranemertes peregrina Coe, 1901 (Emplectonematidae) (Figure 3) [70]. However, anabaseine had already been synthesized in the laboratory in the 1930s as an analogue of nicotine, and has more recently been found as a venom in the ant species Nemertines and Aphaenogaster [69]. The venom acts as an agonist of acetylcholine on peripheral neuromuscular nicotinic receptors [71]. In vertebrates, however, it stimulates neuromuscular nicotinic receptors in the central and peripheral nervous system [71], causing depolarization of neurons and release of both dopamine and norepinephrine [71]. As such, it has the potential as a treatment of cognitive function loss. A synthetic anabaseine analogue, DMXBA (GTS-21) has exhibited memory-enhancing effects in recipients [70]. Both anabaseine and DMXBA are under clinical evaluation as a treatment for Alzheimer's disease.

\section{Bioactive compounds from Mollusca}

With over 130,000 living species, the Mollusca comprise the second largest animal phylum after the Arthropoda. They have an evolutionary history extending back to the Precambrian, roughly 555 million years ago. This phylum includes slugs, snails, squids, cuttlefish, octopuses, as well as a large variety of marine shellfish such as clams, mussels, and oysters. Arthropods are the most common marine animals, occupying virtually every niche in the oceans. Exploration of this phylum has led to the identification of various unusual structures with exciting biological activities such as dolastatin 10, kahalalide F, spisulosine, and ziconotide.

\section{Dolastatin 10}

The linear pentapeptide dolastatin 10 was isolated from the marine sea hare Dolabella auricularia Lightfoot, 1786 (Aplysiidae) which

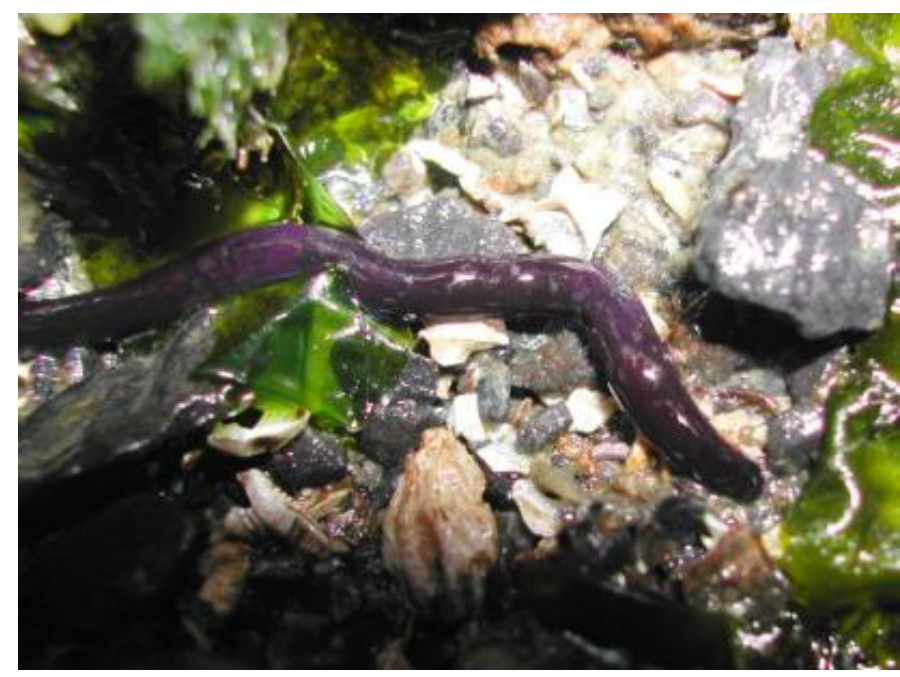

Figure 3. The nemertine worm Paranemertes peregrina (Emplectonematidae) From: soundwaterstewards.org 
can be found in the Indian Ocean as well as the Western and Northwestern Pacific [72]. However, this compound is not actually produced by $D$. auricularia but by blue-green algae grazed by this sea hare [73]. Dolastatin 10 binds to the vinca/peptide region of tubulin resulting in inhibition of microtubule assembly, the formation of tubulin aggregates, and disruption of mitosis [74]. It also induces tumor cell apoptosis by targeting the oncoprotein bcl- 2 that is overexpressed in certain cancers [75]. Phase II clinical trials with single-agent dolostatin 10 against a wide range of tumors did not show meaningful antineoplastic activity [76]. Still, this agent and several analogues are currently under evaluation in combination drug regimens against difficult-to-treat malignancies such as malignant melanoma as well as renal and pancreatic cancer [77].

\section{Kahalalide F}

Kahalalide $\mathrm{F}$ is so far the only known member of the kahalide family of peptides and has been isolated from the Hawaiian herbivorous marine sacoglossan mollusk Elysia rufescens Pease, 1871 (Plakobranchidae) $[78,79]$. Like dolastatin 10 , the mollusc produces kahalalide $\mathrm{F}$ as a secondary metabolite from substances in its diet of (green) algae [78,79]. Kahalalide F acts as a cytotoxin that disrupts lysosomal membranes in (tumor) cells, thereby initiating apoptosis $[80,81]$. It also interferes with the expression of genes involved in DNA replication and cell proliferation thereby inhibiting tumor spread and growth $[80,81]$. The drug showed promise against a broad range of tumors and is in clinical trial in patients with, among others, prostate cancer $[82,83]$. It is also being tested for its therapeutic efficacy against several dermatological conditions [82].

\section{Spisulosine}

Spisulosine is a sphingoid-type base that was first isolated from the North Arctic surf clam Spisula polynyma Stimpson, 1860 (Mactridae) [84]. This substance exhibited potent cytotoxicity in preclinical studies $[84,85]$ through an unprecedented mechanism of action: the induction of changes in the shape of the cytoskeleton [85]. Thus, spisulosine prevented the formation of actin stress fibers in cultured cells - probably by decreasing the activity of Rho proteins - resulting in perturbation of cell adhesion, migration, and morphogenesis [85] and eventually apoptosis [86]. Spisulosine is currently under clinical evaluation as an antitumor agent [87]. However, S. polynyma reaches reproductive maturity only at an age of 5 to 8 years which hampered a regular supply of spisulosine from this source. For this reason, efforts are being dedicated to the production of a more rapidly growing variant of $S$. polynyma that can be maintained in aquaculture in order to commercially produce sufficient spisulosine for drug development purposes [88].

\section{Ziconotide}

Ziconotide (or SNX-111 or Prialt ${ }^{\circledR}$ ) is a synthetic form of a newly described chemical family of short peptides (25 to 30 amino acids in length) called conotoxin peptides [89], and is probably among the most exciting marine natural compounds ever identified. Conotoxin peptides were first extracted from the venom of the predatory cone snails Conus geographicus Linnaeus, 1758, and Conus magus Linnaeus, 1758 (Conidae) (Figure 4) [90]. These snails live in the coral reefs surrounding Australia, Indonesia, and the Philippines, and hunt and kill prey using the powerful neurotoxins in their venom [91]. Each species of cone snail produces its own cocktail of unique venoms containing dozens of nerve toxins, some of which instantly shock the prey while others cause paralysis [91]. Ziconotide was molded on the

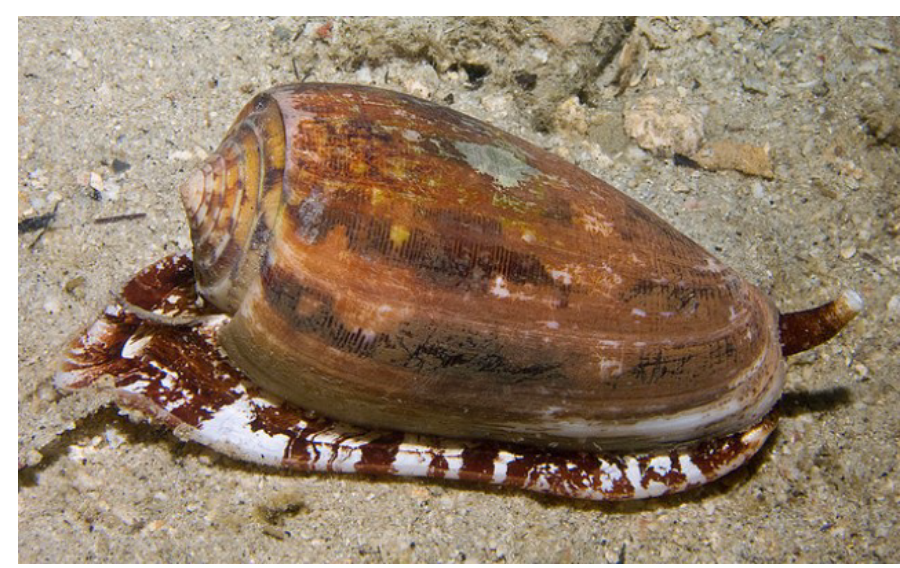

Figure 4. The predatory marine cone snail Conus gheographicus (Conidae) From: www.duikvakanties.net

basis of the peptides found in cone snail venom due to their potential to act as pain-killing drugs [92].

Ziconotide is administered through intrathecal injection because it does not cross the blood-brain barrier [93]. It precisely blocks N-type calcium channels in pain-transmitting nerve cells, rendering them unable to transmit pain signals to the brain $[93,94]$ while the rest of the nervous system continues to function properly $[93,94]$. Obviously, this represents an important advantage of ziconotide over currently available opiate pain killers. Of note, ziconotide's efficacy in treating pain exceeds that of morphine by fifty to several thousand times $[93,94]$, but because it is non-addictive it may be suitable for longterm use. Ziconotide also does not cause the dreadful side-effects of morphine such as sedation and respiratory depression $[93,94]$. As a result, this drug has been approved for the management of chronic pain in patients suffering from among others, AIDS and cancer.

\section{Bioactive compounds from Bryozoa}

The phylum Bryozoa comprises approximately 5,000 species of colony-forming aquatic invertebrate animals that build networks of branching tubes attached to the sea bed. Bryozoans are also known as moss animals because of the similarity of the branching colonies with moss. The small animals attach to aquatic plants, woody debris, stones, and even snail shells, and are often responsible for biofouling on ships' hulls, docks, marinas, and offshore structures. They typically extend a crown of retractable tentacles lined with cilia (the lophophore) into the current to sieve small drifting food particles out of the water. Most bryozoans produce deterrent chemicals that protect them from predation by making them unpalatable to their attackers [95]. Several of such compounds belong to the group of bryostatins [95].

\section{Bryostatin 1}

Bryostatin 1 is a member of a group of twenty different macrolide lactones first isolated from extracts of the bryozoan marine invertebrate Bugula neritina Linnaeus, 1758 (Bugulidae) (Figure 5) [95]. Together with other bryostatins, this compound probably defends the highly vulnerable larval stages of $B$. neritina from fish predation [95]. Due to its capacity to potently modulate protein kinase $C$ activity [96], bryostatin 1 has been evaluated as an anticancer agent [96]. In preclinical studies, it inhibited cell growth and angiogenesis, stimulated cell differentiation and apoptosis, and acted synergistically with various other anti-cancer drugs [96]. However, when tested as a single agent in phase II trials in tumor patients, it demonstrated only moderate activity while toxicities 


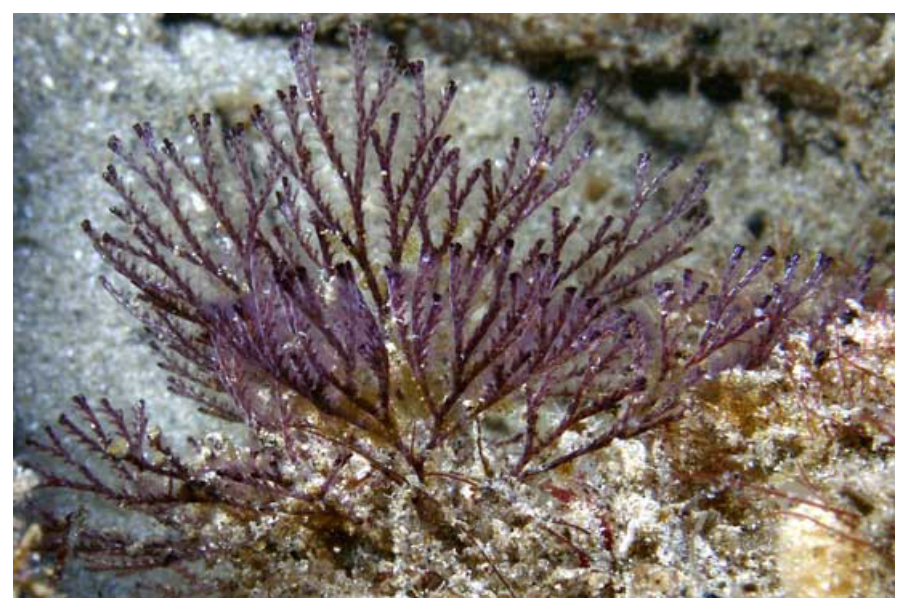

Figure 5. The bryozoan Bugula neritina (Bugulidae)

From: www.roboastra.com

were substantial [96]. For these reasons, research focus has shifted to combinations of bryostatin 1with other antitumor agents [96].

Bryostatin 1 also produced very promising results in enhancing memory in animal models. It increased the duration of memory retention of a sea snail by over 500\% [97], improved learning capacity in laboratory animals [98] including a transgenic a mouse model of Alzheimer's disease [99], and alleviated brain damage in ischemically brain-injured rats [100]. These observations signify potential therapeutic applications for bryostatins other than those related to neoplastic disease.

\section{Bioactive compounds from Tunicata}

The Tunicata comprise a subphylum of about 2,150 species of marine invertebrates with a unique outer covering or 'tunic' that is formed from proteins and carbohydrates and serves as an exoskeleton. Various species are known as sea squirts (because they contract their bodies sharply and squirt out water when disturbed), sea pork or sea liver (because of the resemblance of their dead colonies to pieces of meat), or sea tulips (because of their colorful bodies on slender stalks). Tunicates have a water-filled, sac-like body and two tubular openings through which they draw in and expel water for filter-feeding. Some species accumulate large amounts of vanadium, lithium, iron, niobium, or tantalum in vacuoles in the presence of sulphuric acid, and deposit these substances just below the outer surface of their tunic in order to deter predation [101]. Others produce distasteful organic compounds as chemical defenses against predators [102]. Such compounds - among others, mandelalides, trabectedin, and plitidepsin - have potentially useful medicinal properties.

\section{Mandelalides}

Mandelalides A to D are variously glycosylated, unusual polyketide macrolides isolated in 2012 from the newly described South African tunicate Lissoclinum sp. (Didemnidae) [103]. Strikingly, mandelalides $\mathrm{A}$ and $\mathrm{B}$ exhibited cytotoxicity at nanomolar concentrations in human tumor cell lines [103]. However, these compounds could only be obtained at too low quantities from the tunicate to allow studies on their mechanism(s) of action and molecular targets (s). For this reason, several successful efforts have been undertaken to provide a reliable synthetic supply of particularly mandelalide $A$, the most active compound of this series of marine macrolides [104-107]. This was expected to open the door for biochemical and pharmacological studies with these promising cytotoxic compounds.

Unfortunately, the previously reported potent biological activity of the naturally-occurring mandelalides $A$ and $B$ [103] could not be reproduced with synthetic mandelalide A [104,107]. So far, the reasons for this discrepancy are not known. However, applying shotgun metagenomic sequencing of DNA extracted from Lissoclinum $\mathrm{sp}$, it could be deduced that the mandelalides were not produced by Lissoclinum sp. but by a bacterial symbiont of the tunicate belonging to the phylum Verrucomicrobia [108]. It is hoped that this discovery will shed more light on the precise configurations of the bioactive mandelalides in order to continue the further development of this exciting class of marine compounds.

\section{Trabectedin}

Trabectedin (or ecteinascidin 743 , ET-743, or Yondelis ${ }^{\circ}$ ) is a tetrahydroisoquinoline alkaloid that was originally isolated from the Caribbean sea squirt Ecteinascidia turbinata Herdman, 1880 (Perophoridae) (Figure 6) found in the West Indies around the roots of intertidal and subtidal mangroves [84]. Subsequent studies found that the compound is in fact produced by Candidatus Endoecteinascidia frumentensis, a microbial symbiont of the tunicate [109]. Preclinical and early clinical studies showed appreciable activity of trabectedin against a range of tumor types including soft tissue sarcomas [110,111]. This occurs through a unique mechanism of action: the production of superoxide near the nuclear DNA of tumor cells resulting in DNA backbone cleavage and tumor cell apoptosis [112]. Importantly, only cells engaged in active gene transcription undergo apoptosis [112], suggesting that trabectedin has substantial specificity to cancer cells which in general exhibit greatly accelerated transcription and translation rates when compared to normal cells.

Trabectedin also interfered with the $m d r 1$ gene [113] that encodes for the plasma membrane-bound P-glycoprotein which confers multidrug resistance to cancer cells by actively transporting anticancer drugs out of the cells. This suggests a role for trabectedin as a key ingredient in combination chemotherapy regimens to prevent tumor cells from developing resistance to the other drugs. Trabectedin has been granted orphan status against advanced soft tissue sarcomas [114] and is currently undergoing clinical trials for the treatment of various other malignancies [115].

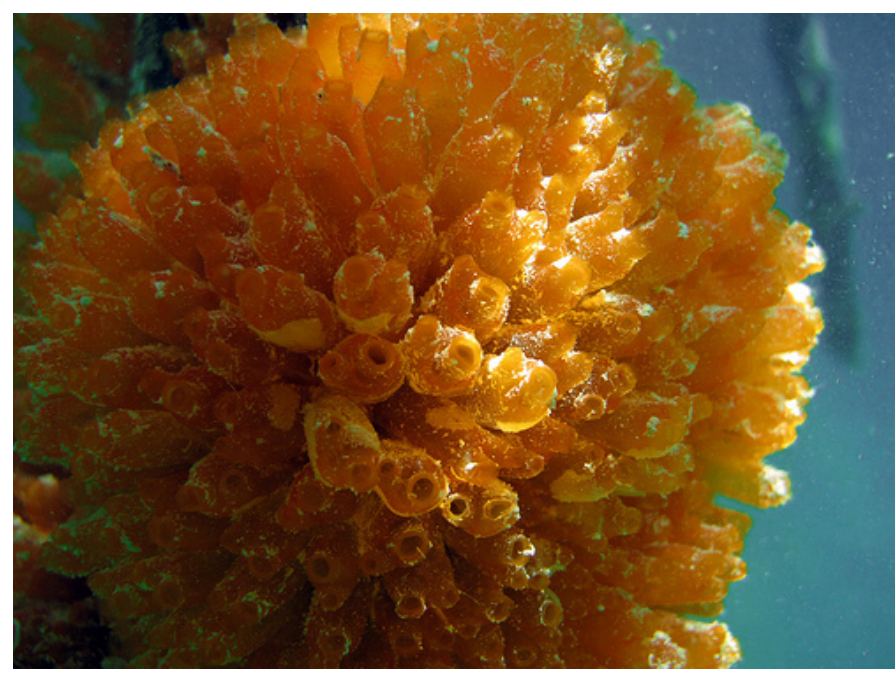

Figure 6. The Caribbean sea squirt Ecteinascidia turbinate (Perophoridae) From: bioweb.uwlax.edu 


\section{Plitidepsin}

Plitidepsin (or dehydrodidemnin B or Aplidin ${ }^{\circ}$ ) is a member of a class of cyclic depsipeptides that can be extracted from the Mediterranean sea squirt Aplidium albicans Milne-Edwards, 1841 (Polyclinidae) [116] but is currently produced by chemical synthesis [117]. Plitidepsin exhibited marked anticancer properties in preclinical studies $[118,119]$. These effects are believed to occur through multiple mechanisms including rapid and persistent activation of apoptosis [120] and interruption of the tumor cell cycle at the $G_{1}-G_{2}$ border [121], as well as inhibition of ornithine decarboxylase receptor and vascular endothelial growth factor receptor expression involved in the growth and vascularization of certain tumor types [121]. Notably, plitidepsin seemed to exhibit a high specificity for tumor cells and to induce low toxicity to the normal tissues $[120,121]$. The drug has been granted orphan status in Europe in 2003 for treating acute lymphoblastic leukemia [122] and is being developed for the potential treatment of a variety of cancers [123].

\section{Bioactive compounds from Hemichordata}

The Hemichordata comprise a relatively small phylum (only a few hundred species) of worm-like marine invertebrates [124]. They feed on small particles of organic matter either as filter feeders of as substrate eaters [124], and can be found both in shallow coastal waters and in the deeper seas [124]. Their body can be distinguished into a short proboscis, a collar which may bear tentacles, and a trunk which contains the digestive and reproductive organs [124].

Hemichordata have provided important insights into the evolution of the Deuterostomia because of their pharyngeal gill slits [124,125]. Some of these marine are also known to produce and accumulate various toxic substances - such as halogenated phenols and pyrroles [126] - that may or may not deter predators [126]. More recently, cephalostatin 1 has emerged as a highly interesting bioactive compound from a marine tube worm.

\section{Cephalostatin 1}

Cephalostatin 1 is a bis-steroidal pyrazine alkaloid isolated from the small hemichordate Cephalodiscus gilchristi Ridewood, 1908 (Cephalodiscidae) [127] that can be encountered at the South Africa's temperate southern coast [128]. Evaluation in the in vitro screen of the US National Cancer Institute showed that cephalostatin 1 is an extremely potent inhibitor of cell proliferation, inhibiting tumor cell growth at subnanomolar to nanomolar concentrations [127,129]. Furthermore, its unique cytotoxicity profile in this screen suggested a novel mechanism of action that turned out to involve activation of anew, unusual pathway for apoptosis: the selective induction of Smac/ DIABLO (second mitochondria-derived activator of caspases/direct inhibitor of apoptosis-binding protein with a low isoelectric point) as a mitochondrial signaling molecule $[127,130,131]$. Notably, this process occurred without the release of cytochrome $\mathrm{c}$ from the mitochondria [127,130,131] but required caspase 9 activation [127] following stimulation by endoplasmic reticulum stress-associated caspase 4 [129].

These observations suggest that cephalostatin 1 may be particularly useful for treating chemo-resistant malignancies. For this reason, this compound is now in preclinical development. Unfortunately, the availability of this compound as well as other cephalostatins from C. gilchristi - their only known natural source - is extremely limited, which restricts their further evaluation and subsequent preclinical development.

\section{Future prospects and concluding remarks}

The extraordinary biological and chemical diversity of marine invertebrates addressed in this paper illustrates the potential of this largely untapped source for the discovery and development of new therapeutics. However, this enterprise poses unprecedented challenges to molecular biologists, pharmacologists, clinical chemists, and chemical ecologists who are active in this comparatively new scientific field. Apart from technological, financial, and regulatory issues, many of these challenges are related to the supply issue: how can the sustainable use of these resources be ensured? Indeed, the regular supply of raw material is a major limiting factor for the further pharmaceutical development of many marine-derived compounds.

Often, the bioactive compound of interest is present in trace amounts in the organism, and supply from wild harvest poses many logistic problems and usually does not provide enough of the compound for even preclinical studies. For instance, the sponge $D$. dissoluta must be harvested at a minimum depth of thirty-three meters to obtain the relative modest content of $0.002 \%$ of the light-sensitive drug discodermolide [34], and roughly one tonne of animals is needed to extract one gram of trabectedin [84] or bryostatin [95] while about five grams are needed for a clinical study [84,95].

Attempts to solve these problems through total synthesis have often proved difficult due to the structural complexity of the compounds of interest [132]. More success has been achieved with hemi-synthesis starting from a more readily available natural precursor [133] and the synthesis of structurally simpler analogues with a similar biological profile and in some cases greater pharmacological potency [134,135]. Controlled harvesting, aquaculture of the source organism, in vitro production through cell culture, and transgenic production have also proved feasible alternatives to obtain certain bioactive marine compounds in sufficient quantities [136,137].

More recently, an increasing number of natural products from higher animals have been found to ultimately derive from a bacterial symbiont. A few examples have been given throughout this paper $[73,78,108]$. These 'misses' could for an important part be attributed to genome sequencing and genomics that largely relied on cultivated clonal cultures. The application of metagenomics - the direct genetic analysis of genomes contained with an environmental sample provides access to the functional gene composition of entire microbial communities [138-140]. Thus, metagenomics may help uncovering the enormous functional gene diversity in marine samples, aiding to the identification and production of drug candidates from microbial origin for pre-clinical and clinical development.

These advances, together with new technologies to explore the oceans of our planet (such as probes, sensors, and miniaturized tools that can function in harsh environments) will one day help to explore marine invertebrates and other deep sea resources to their full potential. Undoubtedly, this will lead to the discovery and development of unprecedented new medical treatments, nutritional supplements, pesticides, cosmetics, and other commercial products for the benefit of mankind.

\section{References}

1. Mans DR, da Rocha AB, Schwartsmann G (2000) Anti-cancer drug discovery and development in Brazil: targeted plant collection as a rational strategy to acquire candidate anti-cancer compounds. Oncologist 5: 185-198. [Crossref]

2. Mans DRA (2013) From forest to pharmacy: plant-based traditional medicines as sources for novel therapeutics. Academia J Med Plants 1: 101-110. 
3. Newman DJ, Cragg GM (2004) Marine natural products and related compounds in clinical and advanced preclinical trials. J Nat Prod 67: 1216-1238. [Crossref]

4. Villa FA, Gerwick L (2010) Marine natural product drug discovery: leads for treatment of inflammation, cancer, infections, and neurological disorders. Immunopharmacol Immunotoxicol 32: 228-337. [Crossref]

5. Agatonovic-Kustrin S, Morton DW (2013) Cosmeceuticals derived from bioactive substances found in marine algae. Oceanography 1: 106.

6. Thomas NV, Kim SK (2013) Beneficial effects of marine algal compounds in cosmeceuticals. Mar Drugs 11: 146-164. [Crossref]

7. Lichtman MA (2013) A historical perspective on the development of the cytarabine (7days) and daunorubicin (3days) treatment regimen for acute myelogenous leukemia: 2013 the 40th anniversary of 7+3. Blood Cells Mol Dis 50: 119-130. [Crossref]

8. Proksch P (1994) Defensive roles for secondary metabolites from marine sponges and sponge-feeding nudibranchs. Toxicon 32: 639-655. [Crossref]

9. Hay ME (2009) Marine chemical ecology: chemical signals and cues structure marine populations, communities, and ecosystems. Ann Rev Mar Sci 1: 193-212. [Crossref]

10. Bergmann W, Feeney RJ (1950) The isolation of a new thymine pentoside from sponges 1. J Am Chem Soc 72: 2809-2810.

11. Gul W, Hamann MT (2005) Indole alkaloid marine natural products: an established source of cancer drug leads with considerable promise for the control of parasitic, neurological and other diseases. Life Sci 78: 442-453. [Crossref]

12. Cherkasov A, Hsing M, Zoraghi R, Foster LJ, See RH, et al. (2011) Mapping the protein interaction network in methicillin-resistant Staphylococcus aureus. J Proteome Res 10: 1139-1150. [Crossref]

13. Zoraghi R, See RH, Axerio-Cilies P, Kumar NS, Gong H, et al. (2011) Identification of pyruvate kinase in methicillin-resistant Staphylococcus aureus as a novel antimicrobial drug target. Antimicrob Agents Chemother 55: 2042-2053. [Crossref]

14. Hiramatsu K, Cui L, Kuroda M, Ito T (2001) The emergence and evolution of methicillin-resistant Staphylococcus aureus. Trends Microbiol 9: 486-493. [Crossref]

15. Alanis AJ (2005) Resistance to antibiotics: are we in the post-antibiotic era? Arch Med Res 36: 697-705. [Crossref]

16. Lewis K (2013) Platforms for antibiotic discovery. Nat Rev Drug Discov 12: 371-387. [Crossref]

17. França PHB, Barbosa DP, da Silva DL, Ribeiro EAN, Santana AEG, et al. (2014) Indole alkaloids from marine sources as potential leads against infectious diseases. Biomed Res Int 2014: 375423. [Crossref]

18. Davies-Coleman MT, Veale CG2 (2015) Recent Advances in Drug Discovery from South African Marine Invertebrates. Mar Drugs 13: 6366-6383. [Crossref]

19. Caspar Y, Jeanty M, Blu J, Burchak O, Le Pihive E, et al. (2015) Novel synthetic bisindolic derivatives with antistaphylococcal activity, including against MRSA and VISA strains. J Antimicrob Chemother 70: 1727-1737. [Crossref]

20. Veale CGL, Zoraghi R, Young RM, Morrison J, Pretheeban M, et al. (2015) Synthetic analogues of the marine bisindole deoxytopsentin: potent selective inhibitors of MRSA pyruvate kinase. J Nat Prod 78: 355-362. [Crossref]

21. Burgoyne DL, Andersen RJ, Allen TM (1992) Contignasterol, a highly oxygenated steroid with the unnatural 14-beta configuration from the marine sponge Petrosia contignata Thiele, 1899. J Org Chem 57: 525-528.

22. Takei M, Burgoyne DL, Andersen RJ (1994) Effect of contignasterol on histamine release induced by anti-immunoglobulin E from rat peritoneal mast cells. J Pharm Sci 83: 1234-1235. [Crossref]

23. Bramley AM, Langlands JM, Jones AK, Burgoyne DL, Li Y, et al. (1995) Effects of IZP-94005 (contignasterol) on antigen-induced bronchial responsiveness in ovalbuminsensitized guinea-pigs. Br J Pharmacol 115: 1433-1438. [Crossref]

24. Coulson FR, O'Donnell SR (2000) The effects of contignasterol (IZP-94,005) on allergen-induced plasma protein exudation in the tracheobronchial airways of sensitized guinea-pigs in vivo. Inflamm Res 49: 123-127. [Crossref]

25. Andersen RJ, Allen TM, Burgoyne DL (1996) Patent application, US005506221A, Apr.9, 1996.

26. Curman D, Cinel B, Williams DE, Rundle N, Block WD, et al. (2001) Inhibition of the G2 DNA damage checkpoint and of protein kinases Chk1 and Chk2 by the marine sponge alkaloid debromohymenialdisine. J Biol Chem 276: 17914-17919. [Crossref]

27. Jobson AG, Lountos GT, Lorenzi PL, Llamas J, Connelly J, et al. (2009) Cellular inhibition of checkpoint kinase 2 (Chk2) and potentiation of camptothecins and radiation by the novel Chk2 inhibitor PV1019 [7-nitro-1H-indole-2-carboxylic acid \{4-[1-(guanidinohydrazone)-ethyl]-phenyl\}-amide]. Pharmacol Exp Ther 331: 816826. [Crossref]

28. Nguyen TN, Saleem RS, Luderer MJ, Hovde S, Henry RW, et al. (2012) Radioprotection by hymenialdisine-derived checkpoint kinase 2 inhibitors. ACS Chem Biol 7: 172-184. [Crossref]

29. Takai H, Naka K, Okada Y, Watanabe M, Harada N, et al. (2002) Chk2-deficient mice exhibit radioresistance and defective p53-mediated transcription. EMBO J 21: 51955205. [Crossref]

30. Kawabe T (2004) G2 checkpoint abrogators as anticancer drugs. Mol Cancer Ther 3 513-519. [Crossref]

31. Mandelkow EM, Mandelkow E (1998) Tau in Alzheimer's disease. Trends Cell Biol 8: 425-427. [Crossref]

32. Martinez A, Castro A, Dorronsoro I, Alonso M (2002) Glycogen synthase kinase 3 (GSK-3) inhibitors as new promising drugs for diabetes, neurodegeneration, cancer, and inflammation. Med Res Rev 22: 373-384. [Crossref]

33. OsteoArthritis Sciences, Inc. (1997 The Regents of the University of California. The use of debromohymenialdisine for treating osteoarthritis.US Patent 5,591,740, 1997.

34. Gunasekera SP, Gunasekera M, Longley RE, Schulte GK (1990) Discodermolide: a new bioactive polyhydroxylated lactone from the marine sponge Discodermia dissoluta. J Org Chem 55: 4912-4915.

35. Longley RE, Gunasekera SP, Faherty D, Mclane J, Dumont F (1993) Immunosuppression by discodermolide. Ann N Y Acad Sci 696: 94-107. [Crossref]

36. Martello LA, McDaid HM, Regl DL, Yang CP, Meng D, et al. (2000) Taxol and discodermolide represent a synergistic drug combination in human carcinoma cell lines. Clin Cancer Res 6: 1978-1987. [Crossref]

37. Mita A, Lockhart AC, Chen TL, Bochinski K, Curtright J, et al. (2004) A phase I pharmacokinetic (PK) trial of XAA296A (discodermolide) administered every 3 wks to adult patients with advanced solid malignancies. J Clin Oncol 22: (Suppl): 2025.

38. Honore S, Kamath K, Braguer D, Horwitz SB, Wilson L, et al. (2004) Synergistic suppression of microtubule dynamics by discodermolide and paclitaxel in non-small cell lung carcinoma cells. Cancer Res 64: 4957-4964. [Crossref]

39. Longley RE, Caddigan D, Harmody D, Gunasekera M, Gunasekera SP (1991) Discodermolide - a new, marine-derived immunosuppressive compound: II. In vivo studies. Transplantation 52: 656-661. [Crossref]

40. Klein LE, Freeze BS, Smith AB 3rd, Horwitz SB (2005) The microtubule stabilizing agent discodermolide is a potent inducer of accelerated cell senescence. Cell Cycle 4 : 501-507. [Crossref]

41. Uemura D, Takahashi K, Yamamoto T, Katayama C, Tanaka J, et al. (1985) Norhalichondrin A: an antitumor polyether macrolide from a marine sponge. $J \mathrm{Am}$ Chem Soc 107: 4796-4798.

42. Hirata Y, Uemura D (1986) Halichondrins - antitumor polyether macrolides from a marine sponge. Pure Appl Chem 58: 701-710.

43. Bai RL, Paull KD, Herald CL, Malspeis L, Pettit GR, et al. (1991) Halichondrin B and homohalichondrin $\mathrm{B}$, marine natural products binding in the vinca domain of tubulin. Discovery of tubulin-based mechanism of action by analysis of differential cytotoxicity data. J Biol Chem 266: 15882-15889. [Crossref]

44. Geldof AA, Mastbergen SC, Henrar RE, Faircloth GT (1999) Cytotoxicity and neurocytotoxicity of new marine anticancer agents evaluated using in vitro assays. Cancer Chemother Pharmacol 44: 312-318. [Crossref]

45. García-Rocha M, García-Gravalos MD, Avila J (1996) Characterisation of antimitotic products from marine organism that disorganise the microtubule network: ecteinascidin 743, isohomohalichondrin-B and LL-15. Br J Cancer 73: 875-883. [Crossref]

46. Bergamaschi D, Ronzoni S, Taverna S, Faretta M, De Feudis P, et al. (1999) Cell cycle perturbations and apoptosis induced by isohomohalichondrin B (IHB), a natural marine compound. Br J Cancer 79: 267-277. [Crossref]

47. Jordan MA, Kamath K, Manna T, Okouneva T, Miller HP, et al. (2005) The primary antimitotic mechanism of action of the synthetic halichondrin E7389 is suppression of microtubule growth. Mol Cancer Ther 4: 1086-1095. [Crossref]

48. Ahond A, Zurita MB, Colin M, Fizames C, Laboute P, et al. (1988) La girolline, nouvelle substance antitumorale extraite de l'éponge, Pseudoxassynca cantharella n. sp. (Axinellidae). C R Acad Sci Paris 307: 145-148. 
49. Tsukamoto S, Yamashita K, Tane K, Kizu R, Ohta T, et al. (2004) Girolline, an antitumor compound isolated from a sponge, induces $\mathrm{G} 2 / \mathrm{M}$ cell cycle arrest and accumulation of polyubiquitinated p53. Biol Pharm Bull 27: 699-701. [Crossref]

50. Faulkner DJ (2000) Marine pharmacology. Antonie Van Leeuwenhoek 77: 135-145. [Crossref]

51. Benoit-Vical F, Saléry M, Soh PN, Ahond A, Poupat C (2008) Girolline: a potential lead structure for antiplasmodial drug research. Planta Med 74: 438-444. [Crossref]

52. Look SA, Fenical W (1987) The seco-pseudopterosins: new anti-inflammatory diterpene-glycosides from a Caribbean gorgonian octocoral of the genus Pseudopterogorgia. Tetrahedron 43: 3363-3370.

53. Mayer AMS, Jacobson PB, Fenical W, Jacobs RS, Glaser KB (1998) Pharmacological characterization of the pseudopterosins: novel anti-inflammatory natural products isolated from the Caribbean soft coral, Pseudopterogorgia elisabethae. Life Sci 62: 401407. [Crossref]

54. Ata A, Kerr RG, Moya CE, Jacobs RS (2003) Identification of anti-inflammatory diterpenes from the marine gorgonian Pseudopterogorgia elisabethae. Tetrahedron 59: 4215-4222. [Crossref]

55. Rodríguez II, Shi Y-P, García OJ, Rodríguez AD, Mayer AMS, et al. (2004) New pseudopterosin and seco-pseudopterosin diterpene glycosides from two Colombian isolates of Pseudopterogorgia elisabethae and their diverse biological activities. J Nat Prod 67:1672-1680.

56. Potts BC, Faulkner DJ, Jacobs RS (1992) Phospholipase A2 inhibitors from marine organisms. J Nat Prod 55: 1701-1717. [Crossref]

57. Kohl AC, Kerr RG (2004) Identification and characterization of the pseudopterosin diterpene cyclase, elisabethatriene synthase, from the marine gorgonian, Pseudopterogorgia elisabethae. Arch Biochem Biophys 424: 97-104. [Crossref]

58. Kijoa A, Sawanwong P (2004) Drugs and cosmetics from the sea. Mar Drugs 2:72-82. [Crossref]

59. Haefner B (2003) Drugs from the deep: marine natural products as drug candidates. Drug Discov Today 8: 536-544. [Crossref]

60. Gross H, König GM (2006) Terpenoids from marine organisms: unique structures and their pharmacological potential. Phytochem Rev 5: 115-141.

61. Correa H, Valenzuela AL, Ospina LF, Duque C (2009) Anti-inflammatory effects of the gorgonian Pseudopterogorgia elisabethae collected at the Islands of Providencia and San Andrés (SW Caribbean). J Inflamm (Lond) 6: 5. [Crossref]

62. Uye S (2008) Blooms of the giant jellyfish Nemopileman omurai: a threat to the fisheries sustainability of the East Asian marginal seas. Plankton Benthos Res 3 (Suppl): 125-131.

63. Omori M, Kitamura M (2004) Taxonomic review of three Japanese species of edible jellyfish (Scyphozoa: Rhizostomeae). Plankton Biol Ecol 51: 36-51.

64. Kim E, Lee S, Kim JS, Yoon WD, Lim D, et al. (2006) Cardiovascular effects of Nemopilema nomurai (Scyphozoa: Rhizostomeae) jellyfish venom in rats. Toxicol Lett 167: 205-211. [Crossref]

65. Kang C, Munawir A, Cha M, Sohn ET, Lee H, et al. (2009) Cytotoxicity and hemolytic activity of jellyfish Nemopilema nomurai (Scyphozoa: Rhizostomeae) venom. Comp Biochem Physiol C Toxicol Pharmacol 150: 85-90. [Crossref]

66. Yue Y, Yu H, Li R, Xing R, Liu S, et al. (2015) Exploring the antibacterial and antifunga potential of jellyfish-associated marine fungi by cultivation-dependent approaches. PLOS ONE 10: e0144394. [Crossref]

67. Gibson R (1995) Nemertean genera and species of the world: an annotated checklist of original names and description citations, synonyms, current taxonomic status, habitats and recorded zoogeographic distribution. J Nat Hist 29: 271-561.

68. McDermott J, Roe P (1985) Food, feeding behavior and feeding ecology of nemerteans. Am Zool 25: 113-125.

69. Wheeler JW, Olubajo O, Storm CB, Duffield RM (1981) Anabaseine: venom alkaloid of aphaenogaster ants. Science 211: 1051-1052. [Crossref]

70. Kem WR, Soti F, Wildeboer K, LeFrancois S, MacDougall K, et al. (2006) The nemertine toxin anabaseine and its derivative DMXBA (GTS-21): chemical and pharmacological properties. Mar Drugs 4: 255-273.

71. Kem WR, Mahnir VM, Papke RL, Lingle CJ (1997) Anabaseine is a potent agonist on muscle and neuronal alpha-bungarotoxin-sensitive nicotinic receptors. J Pharmacol Exp Ther 283: 979-992. [Crossref]
72. Pettit GR, Kamano Y, Herald CL, Tuinman AA, Boettner FE, et al. (1987) The isolation and structure of a remarkable marine animal antineoplastic constituent: dolastatin $10 . J$ Am Chem Soc 109: 6883-6885.

73. Zanchett G, Oliveira-Filho EC (2013) Cyanobacteria and cyanotoxins: from impacts on aquatic ecosystems and human health to anticarcinogenic effects. Toxins (Basel) 5: 1896-1917. [Crossref]

74. Bai RL, Pettit GR, Hamel E (1990) Binding of dolastatin 10 to tubulin at a distinct site for peptide antimitotic agents near the exchangeable nucleotide and vinca alkaloid sites. J Biol Chem 265: 17141-17149. [Crossref]

75. Kalemkerian GP, Ou X, Adil MR, Rosati R, Khoulani MM, et al. (1999) Activity of dolastatin 10 against small-cell lung cancer in vitro and in vivo: induction of apoptosis and bcl-2 modification. Cancer Chemother Pharmacol 43: 507-515. [Crossref]

76. Krug LM, Miller VA, Kalemkerian GP, Kraut MJ, Ng KK, et al. (2000) Phase II study of dolastatin-10 in patients with advanced non-small-cell lung cancer. Ann Oncol 11: 227-228. [Crossref]

77. Pettit GR, Hogan F, Toms S (2011) Antineoplastic agents. 592. Highly effective cancer cell growth inhibitory structural modifications of dolastatin 10. J Nat Prod 74: 962-968. [Crossref]

78. Hamann MT, Scheuer PJ (1993) Kahalalide F: a bioactive depsipeptide from the sacoglossan mollusk Elysia rufescens and the green alga Bryopsis sp. J Am Chem Soc 115: 5825-5826. [Crossref]

79. Hamann MT, Otto CS, Scheuer PJ, Dunbar DC (1996) Kahalalides: Bioactive Peptides from a Marine Mollusk Elysia rufescens and Its Algal Diet Bryopsis sp.(1). J Org Chem 61: 6594-6600. [Crossref]

80. García-Rocha M, Bonay P, Avila J (1996) The antitumoral compound Kahalalide F acts on cell lysosomes. Cancer Lett 99: 43-50. [Crossref]

81. Suárez Y, González L, Cuadrado A, Berciano M, Lafarga M, et al. (2003) Kahalalide F, a new marine-derived compound, induces oncosis in human prostate and breast cancer cells. Mol Cancer Ther 2: 863-872. [Crossref]

82. Cruz LJ, Luque-Ortega JR, Rivas L, Albericio F (2009) Kahalalide F, an antitumor depsipeptide in clinical trials, and its analogues as effective antileishmanial agents. Mol Pharm 6: 813-824. [Crossref]

83. Martín-Algarra S, Espinosa E, Rubió J, López López JJ, Manzano JL, et al. (2009) Phase II study of weekly Kahalalide $\mathrm{F}$ in patients with advanced malignant melanoma. Eur J Cancer 45: 732-735. [Crossref]

84. Rinehart KL (2000) Antitumor compounds from tunicates. Med Res Rev 20: 1-27. [Crossref]

85. Cuadros R, Montejo de Garcinia E, Wandosella F, Faircloth G, Fernández-Sousa JM, et al. (2000) The marine compound spisulosine, an inhibitor of cell proliferation, promotes the disassembly of actin stress fibers. Cancer Lett 152: 23-29. [Crossref]

86. Frisch SM, Francis H (1994) Disruption of epithelial cell-matrix interactions induces apoptosis. J Cell Biol 124: 619-626. [Crossref]

87. Schöffski P, Dumez H, Ruijter R, Miguel-Lillo B, Soto-Matos A, et al. (2011) Spisulosine (ES-285) given as a weekly three-hour intravenous infusion: results of a phase I dose-escalating study in patients with advanced solid malignancies. Cancer Chemother Pharmacol 68: 1397-1403. [Crossref]

88. Dias DA, Urban S, Roessner U3 (2012) A historical overview of natural products in drug discovery. Metabolites 2: 303-336. [Crossref]

89. Skov MJ, Beck JC, de Kater AW, Shopp GM (2007) Nonclinical safety of ziconotide: an intrathecal analgesic of a new pharmaceutical class. Int $J$ Toxicol 26: 411-421. [Crossref]

90. McIntosh M, Cruz LJ, Hunkapiller MW, Gray WR, Olivera BM (1982) Isolation and structure of a peptide toxin from the marine snail Conus magus. Arch Biochem Biophys 218: 329-334. [Crossref]

91. Olivera BM, Rivier J, Clark C, Ramilo CA, Corpuz GP, et al. (1990) Diversity of Conus neuropeptides. Science 249: 257-263. [Crossref]

92. Olivera BM, Teichert RW (2007) Diversity of the neurotoxic Conus peptides: a model for concerted pharmacological discovery. Mol Interv 7: 251-260. [Crossref]

93. Miljanich GP (2004) Ziconotide: neuronal calcium channel blocker for treating severe chronic pain. Curr Med Chem 11: 3029-3040. [Crossref]

94. McGivern JG (2007) Ziconotide: a review of its pharmacology and use in the treatment of pain. Neuropsychiatr Dis Treat 3: 69-85. [Crossref] 
95. Pettit GR, Herald CL, Doubek DL, Herald DL, Arnold E, et al. (1982) Isolation and structure of bryostatin 1. J Am Chem Soc 104: 6846-6848.

96. Mackay HJ, Twelves CJ (2007) Targeting the protein kinase C family: are we there yet? Nat Rev Cancer 7: 554-562. [Crossref]

97. Kuzirian AM, Epstein HT, Gagliardi CJ, Nelson TJ, Sakakibara M, et al. (2006) Bryostatin enhancement of memory in Hermissenda. Biol Bull 210: 201-214. [Crossref]

98. Sun MK, Alkon DL (2005) Dual effects of bryostatin-1 on spatial memory and depression. Eur J Pharmacol 512: 43-51. [Crossref]

99. Schrott LM, Jackson K, Yi P, Dietz F, Johnson GS, et al. (2015) Acute oral Bryostatin-1 administration improves learning deficits in the APP/PS1 transgenic mouse model of Alzheimer's disease. Curr Alzheimer Res 12: 22-31. [Crossref]

100. Sun MK, Hongpaisan J, Alkon DL (2009) Postischemic PKC activation rescues retrograde and anterograde long-term memory. Proc Natl Acad Sci U S A 106: 1467614680. [Crossref]

101. Odate S, Pawlik JR (2007) The role of vanadium in the chemical defense of the solitary tunicate, Phallusia nigra. J Chem Ecol 33: 643-654. [Crossref]

102. Pisut DP, Pawlik JR (2002) Anti-predatory chemical defenses of ascidians: secondary metabolites or inorganic acids? J Exp Mar Biol Ecol 270: 203-214.

103. Sikorska J, Hau AM, Anklin C, Parker-Nance S, Davies-Coleman MT, et al. (2012) Mandelalides A-D, cytotoxic macrolides from a new Lissoclinum species of South African tunicate. J Org Chem 77: 6066-6075. [Crossref]

104. Lei H, Yan J, Yu J, Liu Y, Wang Z, et al. (2014) Total synthesis and stereochemical reassignment of mandelalide A. Angew Chem Int Ed Engl 53: 6533-6537. [Crossref]

105. Willwacher J, Fürstner A (2014) Catalysis-based total synthesis of putative mandelalide A. Angew Chem Int Ed Engl 53: 4217-4221. [Crossref]

106. Brütsch TM, Bucher P, Altmann KH2 (2016) Total Synthesis and Biological Assessment of Mandelalide A. Chemistry 22: 1292-1300. [Crossref]

107. Willwacher J, Heggen B, Wirtz C, Thiel W, Fürstner A (2015) Total synthesis, stereochemical revision, and biological reassessment of mandelalide A: chemical mimicry of intrafamily relationships. Chem Eur J 21: 10416-10430. [Crossref]

108. Weyna TR, Barkei JJ, Miller IJ, McPhail KL, Kwan JC (2015) The mandelalides are produced by a symbiont in the phylum Verrucomicrobia in the tunicate Lissoclinum sp. Planta Med 2015; 81 - PF4.

109. Rath CM, Janto B, Earl J, Ahmed A, Hu FZ, et al. (2011) Meta-omic characterization of the marine invertebrate microbial consortium that produces the chemotherapeutic natural product ET-743. ACS Chem Biol 6: 1244-1256. [Crossref]

110. D'Incalci M, Jimeno J (2003) Preclinical and clinical results with the natural marine product ET-743. Expert Opin Investig Drugs 12: 1843-1853. [Crossref]

111. Fayette J, Coquard IR, Alberti L, Ranchère D, Boyle H, et al. (2005) ET-743: a novel agent with activity in soft tissue sarcomas. Oncologist 10: 827-832. [Crossref]

112. Erba E, Bergamaschi D, Bassano L, Damia G, Ronzoni S, et al. (2001) Ecteinascidin-743 (ET-743), a natural marine compound, with a unique mechanism of action. Eur J Cancer 37: 97-105. [Crossref]

113. Kanzaki A, Takebayashi Y, Ren XQ, Miyashita H, Mori S, et al. (2002) Overcoming multidrug drug resistance in P-glycoprotein/MDR1-overexpressing cell lines by ecteinascidin 743. Mol Cancer Ther 1: 1327-1334. [Crossref]

114. Gettys SC, Anderson JE, Davis JE2 (2013) New and emerging therapies for advanced or metastatic soft tissue sarcoma. J Oncol Pharm Pract 20: 288-297. [Crossref]

115. Monk BJ, Dalton H, Benjamin I, Tanoviä A (2012) Trabectedin as a new chemotherapy option in the treatment of relapsed platinum sensitive ovarian cancer. Curr Pharm Des 18: 3754-3769. [Crossref]

116. Urdiales JL, Morata P, Núñez De Castro I, Sánchez-Jiménez F (1996) Antiproliferative effect of dehydrodidemnin B (DDB), a depsipeptide isolated from Mediterranean tunicates. Cancer Lett 102: 31-37. [Crossref]

117. Gutiérrez-Rodríguez M, Martín-Martínez M, García-López MT, Herranz R, Cuevas F, et al. (2004) Synthesis, conformational analysis, and cytotoxicity of conformationally constrained aplidine and tamandarin A analogues incorporating a spirolactam betaturn mimetic. J Med Chem 47: 5700-5712. [Crossref]

118. Bresters D, Broekhuizen AJ, Kaaijk P, Faircloth GT, Jimeno J, et al. (2003) In vitro cytotoxicity of aplidin and cross-resistance with other cytotoxic drugs in childhood leukemic and normal bone marrow and blood samples: a rational basis for clinical development. Leukemia 17: 1338-1343. [Crossref]
119. Mitsiades CS, Ocio EM, Pandiella A, Maiso P, Gajate C, et al. (2008) Aplidin, a marine organism-derived compound with potent antimyeloma activity in vitro and in vivo. Cancer Res 68: 5216-5225. [Crossref]

120. García-Fernández LF, Losada A, Alcaide V, Alvarez AM, Cuadrado A, et al. (2002) Aplidin induces the mitochondrial apoptotic pathway via oxidative stress-mediated JNK and p38 activation and protein kinase C delta. Oncogene 21: 7533-7544. [Crossref]

121. Muñoz-Alonso MJ, González-Santiago L, Martínez T, Losada A, Galmarini CM, et al. (2009) The mechanism of action of plitidepsin. Curr Opin Investig Drugs 10: 536542. [Crossref]

122. European Medicines Agency. Committee for orphan medicinal products (2005) Public summary of positive opinion for orphan designation of aplidine for the treatment of multiple myeloma. London, UK.

123. Yao L (2003) Aplidin PharmaMar. IDrugs 6: 246-250. [Crossref]

124. Cameron CB (2005) A phylogeny of the hemichordates based on morphological characters. Can J Zool 83: 196-215.

125. Gonzalez P, Cameron CB (2009) The gill slits and pre-oral ciliary organ of Protoglossus (Hemichordata: Enteropneusta) are filter-feeding structures. Biol J Linn Soc 98: 898-906.

126. Giray C, King GM (1997) Predator deterrence and 2,4-dibromophenol conservation by the enteropneusts, Saccoglossus bromophenolosus and Protoglossus graveolens. Mar Ecol Prog Ser 159: 229-238.

127. Iglesias-Arteaga MA, Morzycki JW (2013) Cephalostatins and ritterazines. Alkaloids Chem Biol 72: 153-279. [Crossref]

128. Pettit GR, Inoue M, Kamano Y, Herald DL, Arm C, et al. (1988) Antineoplastic agents 147. Isolation and structure of the powerful cell growth inhibitor cephalostatin 1. J Am Chem Soc 110: 2006-2007.

129. Rudy A, López-Antón N, Barth N, Pettit GR, Dirsch VM, et al. (2008) Role of Smac in cephalostatin-induced cell death. Cell Death Differ 15: 1930-1940. [Crossref]

130. Von Schwarzenberg K, Vollmar AM (2013) Targeting apoptosis pathways by natural compounds in cancer: marine compounds as lead structures and chemical tools for cancer therapy. Cancer Lett 332: 295-303. [Crossref]

131. Dirsch VM, Müller IM, Eichhorst ST, Pettit GR, Kamano Y, et al. (2003) Cephalostatin 1 selectively triggers the release of Smac/DIABLO and subsequent apoptosis that is characterized by an increased density of the mitochondrial matrix. Cancer Res 63 8869-8876. [Crossref]

132. Lu Y, Woo SK, Krische MJ (2011) Total synthesis of bryostatin 7 via C-C bondforming hydrogenation. J Am Chem Soc 133: 13876-13879. [Crossref]

133. Cuevas C, Pérez M, Martín MJ, Chicharro JL, Fernández-Rivas C, et al. (2000) Synthesis of ecteinascidin ET-743 and phthalascidin Pt-650 from cyanosafracin B. Org Lett 2: 2545-2548. [Crossref]

134. Keck GE, Poudel YB, Rudra A, Stephens JC, Kedei N, et al. (2010) Molecular modeling, total synthesis, and biological evaluations of C9-deoxy bryostatin 1. Angew Chem Int Ed Engl 49: 4580-4584. [Crossref]

135. Shen Y, Burgoyne DL (2002) Efficient synthesis of IPL576,092: a novel anti-asthma agent. J Org Chem 67: 3908-3910. [Crossref]

136. Mickel SJ (2004) Toward a commercial synthesis of (+)-discodermolide. Curr Opin Drug Discov Devel 7: 869-881. [Crossref]

137. Pereira AM, Silva LJ, Meisel LM, Pena A (2015) Fluoroquinolones and tetracycline antibiotics in a Portuguese aquaculture system and aquatic surroundings: occurrence and environmental impact. J Toxicol Environ Health A 78: 959-975. [Crossref]

138. Simon C, Daniel R (2011) Metagenomic analyses: past and future trends. Appl Environ Microbiol 77: 1153-1161. [Crossref]

139. Thomas T, Gilbert J, Meyer F (2012) Metagenomics - a guide from sampling to data analysis. Microb Inform Exp 2: 3. [Crossref]

140. Trindade M, van Zyl LJ, Navarro-Fernández J, Abd Elrazak A (2015) Targeted metagenomics as a tool to tap into marine natural product diversity for the discovery and production of drug candidates. Front Microbiol 6: 890. [Crossref]

Copyright: (C2016 Yu DY. This is an open-access article distributed under the terms of the Creative Commons Attribution License, which permits unrestricted use, distribution, and reproduction in any medium, provided the original author and source are credited. 